\title{
Assessment of the Consciousness Energy Healing Treated Withania Somnifera (Ashwagandha) Root Extract Using LC-MS, GC-MS, and NMR Spectroscopy
}

\author{
Mahendra Kumar Trivedi ${ }^{1}$, Alice Branton ${ }^{1}$, Dahryn Trivedi ${ }^{1}$, Gopal Nayak ${ }^{1}$, \\ Barry Dean Wellborn' ${ }^{1}$, Deborah Lea Smith ${ }^{1}$, Dezi Ann Koster ${ }^{1}$, Elizabeth Patric ${ }^{1}$, Jagdish Singh ${ }^{1}$, \\ Kathleen Starr Vagt ${ }^{1}$, Krista Joanne Callas ${ }^{1}$, Kalyan Kumar Sethi ${ }^{2}$, Parthasarathi Panda ${ }^{2}$, \\ Snehasis Jana ${ }^{2, *}$ \\ ${ }^{1}$ Trivedi Global, Inc., Henderson, Nevada, USA \\ ${ }^{2}$ Trivedi Science Research Laboratory Pvt. Ltd., Bhopal, Madhya Pradesh, India
}

Email address:

publication@trivedieffect.com (S. Jana)

${ }^{*}$ Corresponding author

\section{To cite this article:}

Mahendra Kumar Trivedi, Alice Branton, Dahryn Trivedi, Gopal Nayak, Barry Dean Wellborn, Deborah Lea Smith, Dezi Ann Koster, Elizabeth Patric, Jagdish Singh, Kathleen Starr Vagt, Krista Joanne Callas, Kalyan Kumar Sethi, Parthasarathi Panda, Snehasis Jana. Assessment of the Consciousness Energy Healing Treated Withania Somnifera (Ashwagandha) Root Extract Using LC-MS, GC-MS, and NMR Spectroscopy. American Journal of Physical Chemistry. Vol. 6, No. 2, 2017, pp. 20-30. doi: 10.11648/j.ajpc.20170602.12

Received: March 13, 2017; Accepted: March 28, 2017; Published: April 13, 2017

\begin{abstract}
Withania somnifera (Ashwagandha) root extract is an important herbal medicine. The current study was designed to investigate the impact of Consciousness Energy Healing Treatment (The Trivedi Effect ${ }^{\circledR}$ ) on the characteristic properties of the phytoconstituents present in the ashwagandha root extract using LC-MS, GC-MS, and NMR spectroscopy. Ashwagandha root extract was divided into two parts - one part was control (without treatment), while another part was treated with the Consciousness Energy Healing Treatment remotely by seven renowned Biofield Energy Healers and defined as the Biofield Energy Treated sample. The LC-MS analysis revealed that the retention time $\left(\mathrm{R}_{\mathrm{t}}\right)$ of the phytoconstituents remained same in both the control and treated samples, whereas the peak area $\%$ was significantly altered. The peak area $\%$ of the treated sample at $\mathrm{R}_{\mathrm{t}}$ of $5.06,5.24,5.49,5.68,6.78,6.87,8.12,8.22,8.36,8.55,9.02$, and 10.13 minutes were significantly increased in the range of $0.27 \%$ to $146.94 \%$ compared to the control sample. In addition, the peak area\% of the treated sample at $R_{t}$ of 5.29 , $5.36,6.40,6.49,6.56,6.67,7.08,7.37,7.76,7.87,8.02,8.43,8.85,8.97$, and 9.12 minutes were significantly decreased in the range of $1.83 \%$ to $23.53 \%$ compared with the control sample. A total of 18 withanolides such as sitoindoside IX, viscosa lactone B, 24, 25-dihydrowithanolide D, withanolide A, withanone, withaferin A, withanolide D, ixocarpalactone A, withanolide S, withanolide sulfoxide, etc. were proposed with their structure from the molecular mass at $\mathrm{m} / z$ 650, 489, 473, 471,505 , and 992 at retention times of $6.87,7.10,7.87,8.22,8.54$, and 9.11 minutes with the help of GC-MS and NMR data of both the control and Biofield Energy Treated samples. The mass peak intensity values of the Biofield Energy Treated sample at the same retention time in was significantly decreased in the range of $3.99 \%$ to $52.28 \%$ compared with the control sample. These findings suggest that Energy of Consciousness Healing Treatment could be beneficial for altering the concentration of the phytoconstituents in the ashwagandha root extract by modifying their intrinsic physicochemical properties, which might be helpful to improve the bioavailability of active constituents of ashwagandha root extract that might provide better therapeutic response against inflammatory diseases, immunological disorders, arthritis, cancer, diabetes, sexual disorders, aging and other chronic infections.
\end{abstract}

Keywords: Ashwagandha, Consciousness Energy Healing Treatment, Biofield Energy Healers, Biofield Energy Healing Treatment, The Trivedi Effect ${ }^{\circledR}$, LC-MS, Withanolides, GC-MS, NMR 


\section{Introduction}

Worldwide phyto-medicines have the huge demand for the prevention of various diseases and better quality of life due to their impressive therapeutic effects and fewer side effects compared to the modern medicines [1]. Ashwagandha is an ancient Rasayana herb and is popularly known as 'Ashwagandha' or winter cherry or 'Indian ginseng' [2, 3]. Ashwagandha is mostly used in the preparation of pharmaceuticals and nutraceuticals for the prevention and treatment of various diseases such as nervous system and sexual disorders, infectious diseases, diabetes, cancer, immunological disorders, stress, ulcer, arthritis, etc. It is also useful to arrest the aging process, rejuvenate the body and boost the body defense system against infectious disorders as well as to promote the longevity of life [2-6]. Ashwagandha root extract contains majorly oxygenated withanolides along with numerous sitoindosides, alkaloids, withanamides, reducing sugars, peroxidases, glycosides, starch, withanicil, benzyl alcohol, 2-phenyl ethanol, dilcitol, 3, 4, 5-trihydroxy cinnamic acid, benzoic acid phenyl acetic acid, etc. [7-9]. Isolated withanolides possess various pharmacological activities such as antioxidant, anticancer, neuroprotective, immunomodulating, anti-inflammatory, antiarthritic, hepatoprotective, antimicrobial, hypoglycaemic, etc. [10-12]. Thus, ashwagandha root extract was considered as one of the components in a novel proprietary herbomineral formulation which can be used as nutraceutical supplement for the prevention and treatment of various disorders.

A unique vital force preserved by every living organisms which is usually believed to create the source of life is corelated with the soul, spirit, and mind and is also recognized as prana by the Hindus, $k i$ by the Japanese, and $q i$ or chi by the Chinese from the ancient-time. Now-a-days, this hypothetical vital force is considered as the Bioenergetics Field. This energy field is infinite, paradimensional and dynamic electromagnetic field surrounding the human body. This is also known as The Biofield Energy. It can easily flow between the human and environment that leads to the continuous movement or matter of energy $[13,14]$. Thus, the human has the capability to harness energy from the earth, the "Universal Energy Field" and transmit it to any living or nonliving object (s) around the globe. The objects always receive the energy and respond in a useful way. This process is known as Biofield Energy Healing Treatment [15-17]. Biofield (Putative Energy Fields) based Energy Therapies have been practiced worldwide in different health disease profiles [18]. The National Center of Complementary and Integrative Health (NCCIH) has been recognized and accepted Biofield Energy Healing as a Complementary and Alternative Medicine (CAM) health care approach in addition to other therapies, medicines and practices such as natural products, yoga, deep breathing, Tai Chi, chiropractic/osteopathic manipulation, Qi Gong, meditation, special diets, homeopathy, progressive relaxation, massage, guided imagery, acupressure, relaxation techniques, hypnotherapy, acupuncture, healing touch, movement therapy, pilates, mindfulness, rolfing structural integration, Ayurvedic medicine, traditional Chinese herbs and medicines, naturopathy, essential oils, aromatherapy, cranial sacral therapy, Reiki, and applied prayer (as is common in all religions, like Hinduism, Christianity, Buddhism and Judaism) [19]. The Trivedi Effect ${ }^{\circledR}$ - Biofield Energy Treatment has been extensively studied with significant outcomes in many scientific fields such as cancer research [20]; altered antimicrobial sensitivity of pathogenic microbes in biotechnology [21, 22], genetics [23, 24], microbiology [25-27], changing the structure of the atom in relation to the various metals, ceramics, polymers and chemicals materials science [28-30], nutraceuticals [31, 32], pharmaceuticals [33, 34], organic compounds [35-37], and improved overall growth and yield of plants in agricultural science [38, 39].

Modern sophisticated techniques such as highperformance liquid chromatography (HPLC) with photodiode array and evaporative light scattering detection, ultraperformance liquid chromatography (UPLC), electrospray ionization (ESI) normally hyphenated with mass spectrometry, gas chromatography (GC), nuclear magnetic resonance (NMR) are very useful for the metabolite profiling and identification of the crude herbal extract [8, 40-42]. The LC-MS, GC-MS and NMR analysis of ashwagandha root extract revealed the presence of several known withanolides including withaferin $\mathrm{A}$, withanolide $\mathrm{D}$, withanoside IV/VI, withanolide sulfoxide, etc. along with two new withanolides i.e. dihydrowithanolide D and ixocarpalactone A [43]. Thus, LC-MS, GC-MS, and NMR analysis were carried out for the profiling and structure elucidation of the phytoconstituents of the Consciousness Energy Healing Treated (The Trivedi Effect $^{\circledR}$ ) ashwagandha root extract.

\section{Materials and Methods}

\subsection{Chemicals and Reagents}

Ashwagandha root extract was procured from Sanat Product Ltd, India. The HPLC grade acetonitrile and Milli Q water were purchased from Merck and Millipore. All other chemicals used in the experiment were of analytical grade available in India.

\subsection{Energy of Consciousness Healing Treatment Strategies}

Ashwagandha root extract powder was one of the components of the new proprietary herbomineral formulation, developed by our research team and it was used per se as the test compound for the current study. The test compound was divided into two parts, one part of the test compound was treated with Energy of Consciousness Healing Treatment (The Trivedi Effect ${ }^{\circledR}$ ) by renowned Biofield Energy Healers and defined as Biofield Energy Treated sample. The second part of the test compound did not receive any sort of treatment and defined as untreated or control ashwagandha root extract sample. This Biofield 
Energy Treatment was provided by the group of seven renowned Biofield Energy Healers who participated in this study and performed the Biofield Energy Treatment remotely. All seven Biofield Energy Healers were remotely located in the U.S.A., while the test compound was located in the research laboratory of GVK Biosciences Pvt. Ltd., Hyderabad, India. This Consciousness Energy Healing Treatment was provided for 5 minutes through Healer's Unique Energy Transmission process remotely to the test compound under the laboratory conditions. None of the Biofield Energy Healers in this study visited the laboratory in person, nor had any contact with the compounds. Similarly, the control compound was subjected to "sham" healers for 5 minutes, under the same laboratory conditions. The sham healer did not have any knowledge about the Consciousness Energy Healing Treatment. After that, the Biofield Energy Treated and untreated samples were kept in similar sealed conditions and characterized thoroughly by LC-MS, GC-MS and NMR spectroscopy.

\subsection{Characterization}

\subsubsection{Liquid Chromatography Mass Spectrometry (LC-MS)}

The LC-MS analysis of the control and Biofield Energy Treated samples were conducted by following the almost same method as mentioned in the recent literature [43] using The Waters $^{\circledR}$ ACQUITY UPLC, Milford, MA, USA equipped with a binary pump (The Waters ${ }^{\circledR}$ BSM HPLC pump), auto sampler, column heater and a photo-diode array (PDA) detector. A Triple Quad (Waters Quattro Premier XE, USA) mass spectrometer equipped with an electrospray ionization (ESI) source was used for the mass spectrometric analysis. The control and Biofield Energy Treated extract powders were dissolved in dimethyl sulfoxide to afford a 1 $\mathrm{mg} / \mathrm{mL}$ stock solution. An aliquot of $2 \mu \mathrm{L}$ of the stock solution was used for LC-MS analysis with a total run time of $25 \mathrm{~min}$. Mass spectra were recorded in the positive ionization mode and with the full scan $(\mathrm{m} / \mathrm{z} 50-1400)$.

Percent change in peak area $(\%), \mathrm{T}$ was calculated using following equation (1):

$$
\% \text { change in peak area } \%=\frac{\left[\mathrm{T}_{\text {Treated }}-\mathrm{T}_{\text {Control }}\right]}{\mathrm{T}_{\text {Control }}} \times 100
$$

Where, $\mathrm{T}_{\text {Control }}$ and $\mathrm{T}_{\text {Treated }}$ are the peak area $(\%)$ of the control and Biofield Energy Treated samples, respectively.

Similarly, the percent change in mass peak intensity (I) was calculated using equation (2):

$$
\% \text { change in mass peak intensity }=\frac{\left[\mathrm{I}_{\text {Treated }}-\mathrm{I}_{\text {Control }}\right]}{\mathrm{I}_{\text {Control }}} \times 100
$$

Where, $\mathrm{I}_{\text {Control }}$ and $\mathrm{I}_{\text {Treated }}$ are the mass peak intensity of the control and Biofield Energy Treated samples, respectively.

\subsubsection{Gas Chromatography-Mass Spectrometry (GC-MS) Analysis}

GC-MS analysis of the control and Biofield Energy Treated samples were analyzed by following the same procedure as mentioned in the recent scientific literature [43] with the help of Agilent 7890B with 5977A Mass selective detector, USA equipped with a Quadrupole detector with prefilter and flame ionization detector (FID). The control and Biofield Energy Treated extract powders were dissolved in dimethyl sulfoxide to afford a $1 \mathrm{mg} / \mathrm{mL}$ stock solution. An aliquot of $1.0 \mu \mathrm{L}$ of the stock solution was injected with a total run time of $44.0 \mathrm{~min}$. The identification of analyte was performed using the retention time with a comparison of the mass spectra of the identified substances with references.

\subsubsection{Nuclear Magnetic Resonance (NMR) Analysis}

${ }^{1} \mathrm{H}$ NMR and ${ }^{13} \mathrm{C}$ NMR analysis of the control and Biofield Energy Treated samples extract powders were performed on a 400 MHZ VARIAN FT-NMR spectrometer and $100.00 \mathrm{MHz}$ on a VARIAN FT-NMR spectrometer, respectively using the same procedure as mentioned in the recent literature [43]. ${ }^{1} \mathrm{H}$ NMR multiplicities were labelled as singlet (s), doublet (d), doublet of doublet (dd), triplet (t), quartet (q), multiplet (m), broad (br), apparent (app). Chemical shifts $(\delta)$ were in parts per million (ppm) relative to the solvent's residual proton chemical shift $\left(\mathrm{CD}_{3} \mathrm{OD}, \delta=3.31,4.80 \mathrm{ppm}\right)$ and solvent's residual carbon chemical shift $\left(\mathrm{CD}_{3} \mathrm{OD}, \delta=49.15 \mathrm{ppm}\right)$.

\section{Results and Discussion}

The LC chromatograms and their chromatographic data of the control and Biofield Energy Treated samples of ashwagandha root extract are presented in Figure 1. The chromatograms of the control and Biofield Energy Treated samples showed 27 peaks at different retention times (Figure 1). There was no significant change in the retention time of the chromatographic peaks in the Biofield Energy Treated sample compared with the control sample indicated that the polarity of the phytoconstituents in ashwagandha root extract remained unaltered.

The peak area and peak area\% of the Biofield Energy Treated sample were significantly altered compared with the control sample (Table 1). The total peak area of the Biofield Energy Treated sample was significantly decreased by $11.07 \%$ compared with the control sample. The changes in peak area $\%$ are calculated for the Biofield Energy Treated sample compared to the control sample. There was a significant increase in the peak area $\%$ of the Biofield Energy Treated sample in the range of $0.27 \%$ to $146.94 \%$ at $R_{t}$ of 5.06, 5.24, 5.49, 5.68, 6.78, 6.87, 8.12, 8.22, 8.36, 8.55, 9.02, and 10.13 minutes compared with the control sample. Consequently, the peak area\% of the Biofield Energy Treated sample at $\mathrm{R}_{\mathrm{t}}$ of 5.29, 5.36, 6.40, 6.49, 6.56, 6.67, 7.08, 7.37, $7.76,7.87,8.02,8.43,8.85,8.97$, and 9.12 minutes were significantly decreased in the range of $1.83 \%$ to $23.53 \%$, respectively compared to the control sample. The peak area\% provides the relative amounts of components in the chromatogram, when all components respond in the detector and are eluted [43, 44]. Here, the liquid chromatographic conditions for both the control and Biofield Energy Treated samples were same. It is assumed that all the components in both the samples were equally responded in the detector. 
Thus, the provided peak area\% revealed the relative amounts of the phytoconstituents of ashwagandha root extract. The Biofield Energy Healing Treatment might have the significant effect on the relative amount of the phytoconstituents (Table 1). It is presumed that the intrinsic

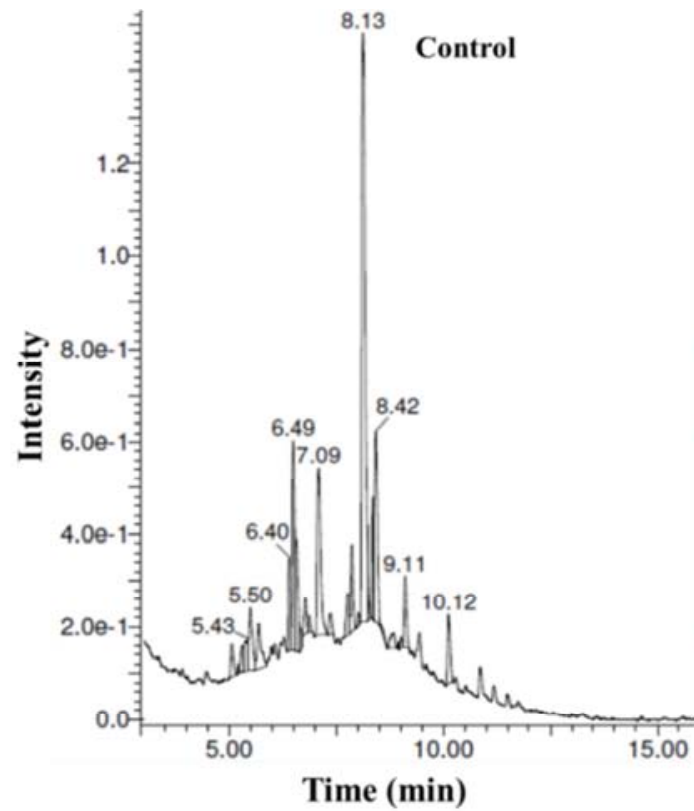

physicochemical properties of ashwagandha root extract such as particle size, shape, etc. of the compounds that are related to the solubility of the compounds might alter due to the Biofield Energy Healing Treatments [28-35].

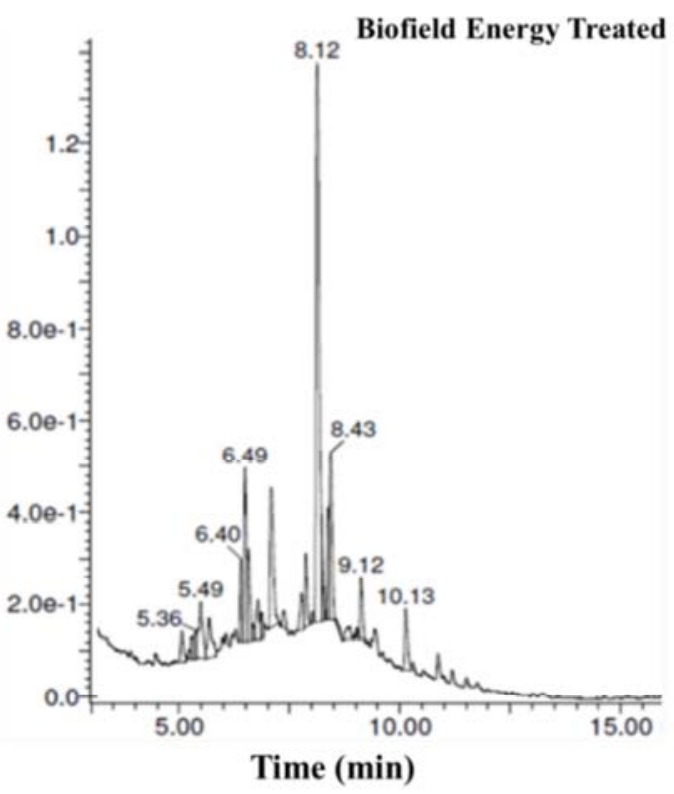

Figure 1. Liquid chromatograms of the control and Biofield Energy Treated Ashwagandha root extract.

Table 1. Liquid chromatographic data of the control and Biofield Energy Treated Ashwagandha root extract.

\begin{tabular}{|c|c|c|c|c|c|c|}
\hline \multicolumn{3}{|l|}{ WS-Control } & \multicolumn{3}{|c|}{ WS-Biofield Energy Treated } & \multirow{2}{*}{ \% Change in PA\%* } \\
\hline Rt & PA & PA\% & Rt & PA & $\mathbf{P A} \%$ & \\
\hline 5.07 & 5470.73 & 1.52 & 5.06 & 5554.45 & 1.73 & 13.82 \\
\hline 5.23 & 803.18 & 0.22 & 5.24 & 862.55 & 0.27 & 22.73 \\
\hline 5.30 & 3931.35 & 1.09 & 5.29 & 3427.94 & 1.07 & -1.83 \\
\hline 5.43 & 5709.42 & 1.58 & 5.36 & 4218.14 & 1.31 & -17.09 \\
\hline 5.50 & 13055.46 & 3.62 & 5.49 & 13137.38 & 4.09 & 12.98 \\
\hline 5.69 & 10460.21 & 2.90 & 5.68 & 10219.93 & 3.18 & 9.66 \\
\hline 6.49 & 30069.85 & 8.33 & 6.49 & 22300.06 & 6.95 & -16.57 \\
\hline 6.57 & 16379.10 & 4.54 & 6.56 & 14115.39 & 4.40 & -3.08 \\
\hline 6.67 & 2541.04 & 0.70 & 6.67 & 1961.75 & 0.61 & -12.86 \\
\hline 6.78 & 4882.91 & 1.35 & 6.78 & 6531.37 & 2.03 & 50.37 \\
\hline 6.87 & 1785.53 & 0.49 & 6.87 & 3890.22 & 1.21 & 146.94 \\
\hline 7.10 & 34004.87 & 9.42 & 7.08 & 27959.10 & 8.71 & -7.54 \\
\hline 7.38 & 3322.77 & 0.92 & 7.37 & 2923.86 & 0.91 & -1.09 \\
\hline 8.02 & 1440.78 & 0.40 & 8.02 & 1149.54 & 0.36 & -10.00 \\
\hline 8.13 & 120220.40 & 33.3 & 8.12 & 107190.3 & 33.39 & 0.27 \\
\hline 8.22 & 5757.36 & 1.59 & 8.22 & 8274.56 & 2.58 & 62.26 \\
\hline 8.36 & 11871.07 & 3.29 & 8.36 & 11463.92 & 3.57 & 8.51 \\
\hline 8.42 & 32038.81 & 8.88 & 8.43 & 26462.51 & 8.24 & -7.21 \\
\hline 8.54 & 1059.00 & 0.29 & 8.55 & 1062.59 & 0.33 & 13.79 \\
\hline 8.84 & 3981.17 & 1.10 & 8.85 & 3333.48 & 1.04 & -5.45 \\
\hline 8.99 & 612.44 & 0.17 & 8.97 & 408.66 & 0.13 & -23.53 \\
\hline 9.01 & 1143.11 & 0.32 & 9.02 & 1113.01 & 0.35 & 9.37 \\
\hline 9.11 & 9990.56 & 2.77 & 9.12 & 8593.14 & 2.68 & -3.25 \\
\hline 10.12 & 10852.50 & 3.01 & 10.13 & 9926.36 & 3.09 & 2.66 \\
\hline Total peak area & 360990.02 & & & 321040.25 & & \\
\hline$\%$ Change in tot & & & & & & -11.07 \\
\hline
\end{tabular}

WS: Withania somnifera, ${ }^{*}$ denotes the percentage change in the peak area (\%) of the Biofield Energy Treated sample with respect to the control sample. 
Six chromatographic peaks out of the 27 peaks, only at the $\mathrm{R}_{\mathrm{t}}$ of $6.87,7.10,7.87,8.22,8.54$, and 9.11 minutes having higher peak area $\%$ are able to characterize with the help of mass spectra and afforded the respective ESI-MS spectra. A total of 18 withanolides were proposed along with GC-MS and NMR data (Figures 2 and 3). Compounds were proposed
(Figures 2 and 3) from the mass of the molecular ion and its fragmentation pattern at the corresponding retention time (Table 2) along with the support of GC-MS and NMR data (Figures $4 \& 5$ ) of the crude extract according to the approach described in our recent literature [43].

Table 2. Compounds proposed from ESI-MS spectra of the control and Biofield Energy Treated ashwagandha root extract.

\begin{tabular}{|c|c|c|c|c|c|}
\hline \multirow{2}{*}{ Rt (min) } & \multirow{2}{*}{ ESI-MS (m/z) } & \multirow{2}{*}{ Proposed Compounds } & \multicolumn{2}{|c|}{ m/z peak Intensity } & \multirow{2}{*}{$\begin{array}{l}\text { \% Change } \\
\text { in Intensity }\end{array}$} \\
\hline & & & Control & Treated & \\
\hline 6.87 & $\begin{array}{l}650\left[\mathrm{M}+\mathrm{NH}_{4}\right]^{+} \\
471[\mathrm{M}-163]^{+}\end{array}$ & Sitoindoside IX (1) & $2.76 \mathrm{e} 6$ & $2.65 \mathrm{e} 6$ & -3.99 \\
\hline 7.10 & $489[\mathrm{M}+\mathrm{H}]^{+}$ & $\begin{array}{l}\beta \text {-Hydroxy-2, 3-dihydro-withanolide F (2) } \\
\text { Viscosa lactone B (3) }\end{array}$ & $1.68 \mathrm{e} 7$ & $1.49 \mathrm{e} 7$ & -11.31 \\
\hline 7.87 & $473[\mathrm{M}+\mathrm{H}]^{+}$ & 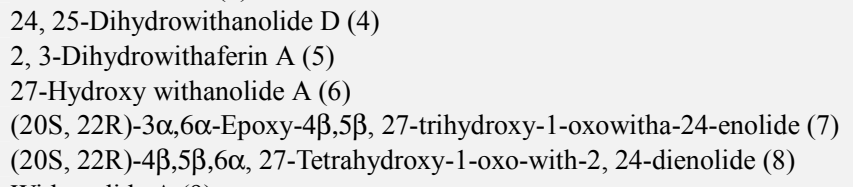 & $1.04 \mathrm{e} 7$ & $7.48 \mathrm{e} 6$ & -28.08 \\
\hline & & $\begin{array}{l}\text { Withanolide A (9) } \\
\text { Withaferine A (10) } \\
\text { Withanone (11) }\end{array}$ & & & \\
\hline 8.22 & $471[\mathrm{M}+\mathrm{H}]^{+}$ & $\begin{array}{l}\text { Withanolide D (12) } \\
\text { 27-Hydroxy Withanolide B (13) } \\
5,7, \alpha \text {-Epoxy-6 } \alpha, 20 \alpha \text {-dihydroxy-1-oxowitha-2, 24-Dienolide (14) } \\
5 \alpha, 17 \text {-Dihydroxy-6 } \alpha, 7 \alpha \text {-epoxy-1-oxo-witha-2, 24-dienolide (15) }\end{array}$ & $7.06 \mathrm{e} 7$ & $6.63 \mathrm{e} 7$ & -6.09 \\
\hline 8.54 & $\begin{array}{l}505[\mathrm{M}+\mathrm{H}]^{+} \\
488[\mathrm{M}-16]^{+}\end{array}$ & $\begin{array}{l}\text { Ixocarpalactone A (16) } \\
\text { Withanolide S (17) }\end{array}$ & $5.26 \mathrm{e} 6$ & $2.51 \mathrm{e} 6$ & -52.28 \\
\hline 9.11 & $992[\mathrm{M}+\mathrm{H}]^{+}$ & Withanolide sulfoxide (18) & $1.69 \mathrm{e} 6$ & $1.31 \mathrm{e} 6$ & -22.49 \\
\hline
\end{tabular}

a denotes the percentage change of the Biofield Energy Treated sample with respect to the control sample.

The LC-MS (Figure 2), GC-MS (Figure 4) and NMR (Figure 5) spectral analysis and following the literature [43] confirmed the presence of the withanolides. At $\mathrm{R}_{\mathrm{t}}$ of 6.87 minutes was sitoindoside IX (1) (Table 2 and Figure 2a) was proposed with the ammonium adduct mass peak at $\mathrm{m} / z 650$ $\left[\mathrm{M}+\mathrm{NH}_{4}\right]^{+}$(calcd for $\mathrm{C}_{34} \mathrm{H}_{52} \mathrm{NO}_{11}, 650$ ) along with $\mathrm{m} / z 471$ $[\mathrm{M}-163]^{+}$in the ESI-MS spectra of the control and Biofield Energy Treated sample. The peak area $\%$ of sitoindoside IX (1) was significantly increased by $146.94 \%$ in the Biofield Energy Treated sample as compared to the control sample (Table 1). It is a glycowithanolide, which is a brain antioxidants and can promote immunomodulation, neuroprotective and memory enhancing activity $[43,45]$. Hydroxy-2, 3-dihydro-withanolide F (2) or viscosa lactone $B$ (3) was identified at $\mathrm{R}_{\mathrm{t}}$ of 7.10 minutes with the molecular mass peak at $m / z 489$ (calcd for $\mathrm{C}_{28} \mathrm{H}_{40} \mathrm{O}_{7}, 489$ ) (Table 2 and Figures $2 \mathrm{~b}$ and 3 ), which have the anti-inflammatory activity $[12,43]$. The peak area $\%$ of it was decreased by $7.54 \%$ in the Biofield Energy Treated sample as compared to the control sample (Table 1). Similarly, the withanolides like 24, 25dihydrowithanolide D (4) or 2, 3-dihydrowithaferin A (5) or 27 -Hydroxy withanolide A (6) or (20S, 22R)-3 $\alpha, 6 \alpha$-Epoxy$4 \beta, 5 \beta, 27$-trihydroxy-1-oxowitha-24-enolide (7) or (20S, $22 \mathrm{R})-\quad 4 \beta, \quad 5 \beta, 6 \alpha, \quad 27-$ Tetrahydroxy-1-oxo-with-2, 24dienolide (8) was proposed at the $\mathrm{R}_{\mathrm{t}}$ of 7.87 minutes with molecular mass peak at $m / z 473[\mathrm{M}+\mathrm{H}]^{+}$(calcd for $\mathrm{C}_{28} \mathrm{H}_{40} \mathrm{O}_{7}$, 489) (Table 2 and Figures 2c and 3). The \% peak area was decreased by $7.02 \%$ in the Biofield Energy Treated sample compared to the control sample (Table 1). The withanolides like withanolide A (9) or withaferine A (10) or withanone (11) or withanolide D (12) or 27-hydroxy withanolide B (13) or 5, 7 $\alpha$-epoxy- $6 \alpha, 20 \alpha$-dihydroxy-1oxowitha-2, 24-dienolide (14) or $5 \alpha, 17 \beta$-dihydroxy- $6 \alpha, 7 \alpha$ epoxy-1-oxo-witha-2, 24-dienolide (15) are proposed at $\mathrm{R}_{\mathrm{t}}$ of 8.22 minutes with molecular mass peak at $m / z 471[\mathrm{M}+\mathrm{H}]^{+}$ (Table 2, Figures 2d and 3). The GC-MS (Figure 4) and NMR data (Figure 5) also supported the presence of any of these compounds 9-15. These compounds had lots of pharmacological activity and used for various disease [2-10, 43]. The peak area $\%$ was increased significantly by $62.26 \%$ in the Biofield Energy Treated sample as compared to the treated sample (Table 1). Ixocarpalactone A (16) or withanolide $\mathrm{S}$ (17) proposed at the $\mathrm{R}_{\mathrm{t}}$ of 8.54 minutes with molecular mass peak at $\mathrm{m} / z$ 505 $[\mathrm{M}+\mathrm{H}]^{+}$(calcd for $\mathrm{C}_{28} \mathrm{H}_{40} \mathrm{O}_{8}, 505$ ) (Table 2 and Figure 2e). The GC-MS (Figure 4) and NMR data (Figure 5) also supported the presence of any of these compounds 16 or 17 . The peak area $\%$ of ixocarpalactone A (16) or withanolide S (17) was increased significantly by $13.79 \%$ in the Biofield Energy Treated sample as compared to the control sample (Table 1). Ixocarpalactone A reported to be promising anti-tumor agent $[43,46,47]$. Similarly, the withanolide proposed at $\mathrm{R}_{\mathrm{t}}$ of 9.11 minutes $m / z 992[\mathrm{M}+\mathrm{H}]^{+}$(calcd for $\mathrm{C}_{56} \mathrm{H}_{79} \mathrm{O}_{13} \mathrm{~S}$, 505) was withanolide sulfoxide (18) (Table 2 and Figure 2f). The GCMS (Figure 4) and NMR data (Figure 5) also supported the presence of any of this compound. The peak area $\%$ of 
withanolide sulfoxide was decreased by $3.25 \%$ in the treated sample as compared to the control sample (Table 1).
Withanolide sulfoxide is a bioactive molecule, effective as an anti-cancer agent $[43,48]$.
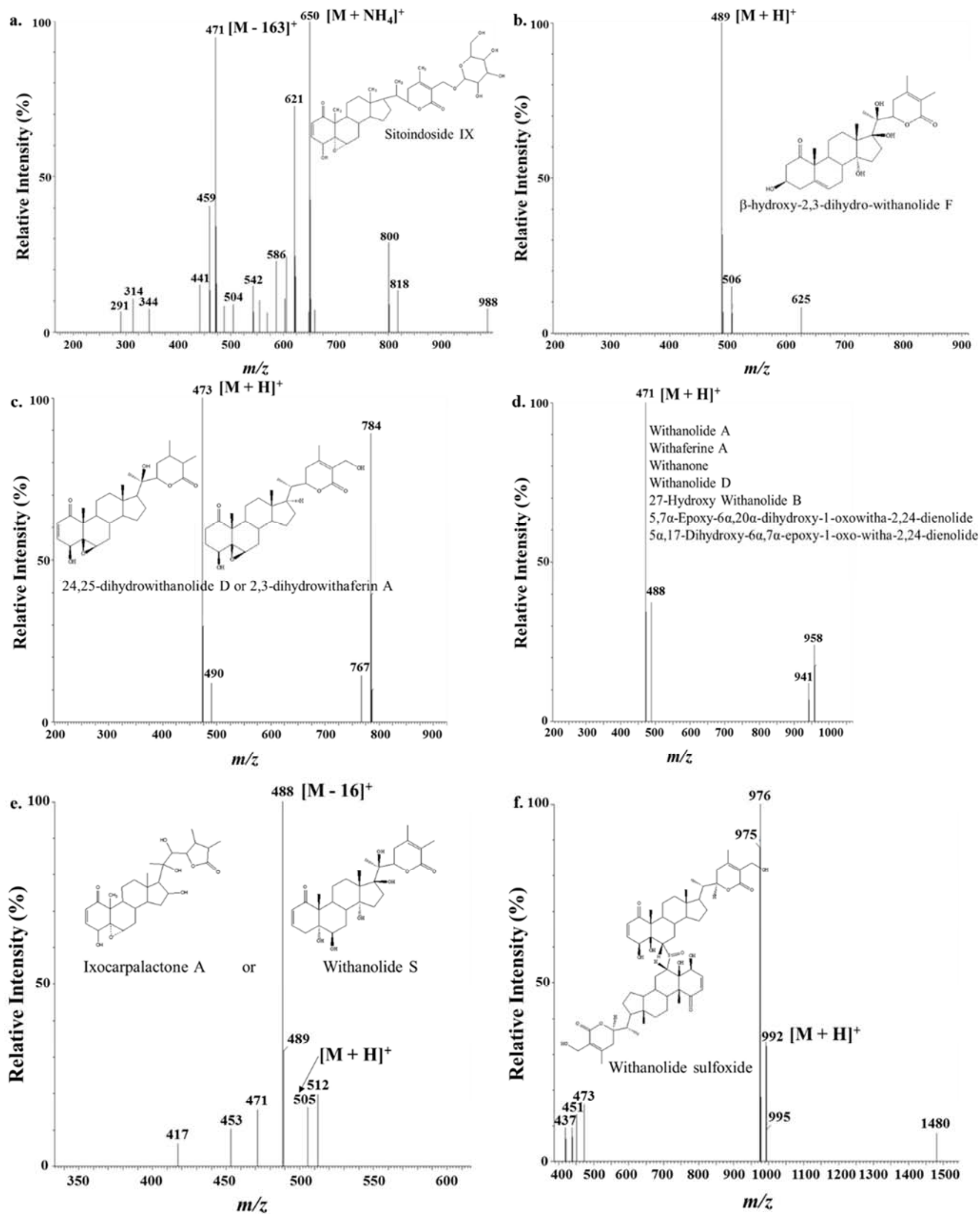

Figure 2. ESI-MS spectra (a-f) showing the possible withanolides (1-14) present in the control and Biofield Energy Treated sample of ashwagandha root extract. 
The LC-MS analytical data of the control and Biofield Energy Treated sample revealed that the mass fragmentation pattern of both the control and Biofield Energy Treated samples were found almost similar. But, the mass peak intensity values were significantly decreased at the same retention time of the Biofield Energy Treated sample in the range of $3.99 \%$ to $52.28 \%$ compared with the control sample. This finding suggests that the natural isotopic abundance ratio of the identified phytoconstituents in the ashwagandha root extract might be altered due to the Consciousness Energy Healing Treatment.

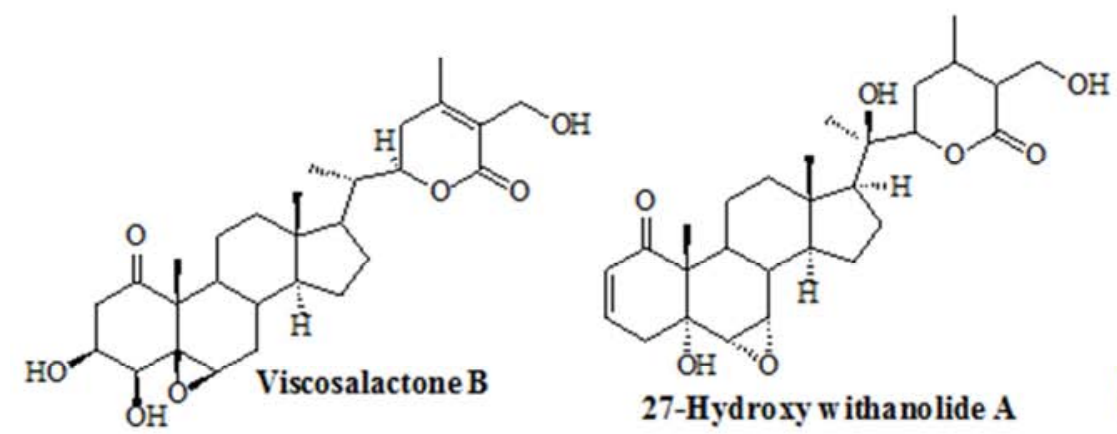

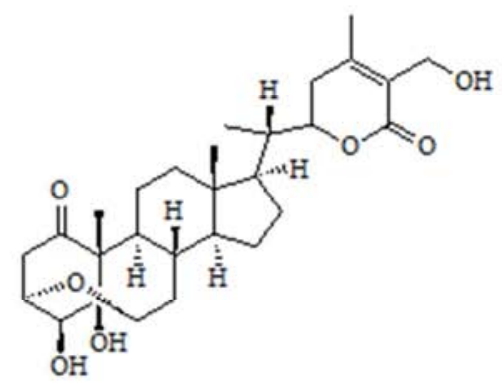

$(20 S, 22 R)-3 a, 6 a$-ep oxy-4b,5b,27-trihydroxy1-oxowitha-24-enolid e

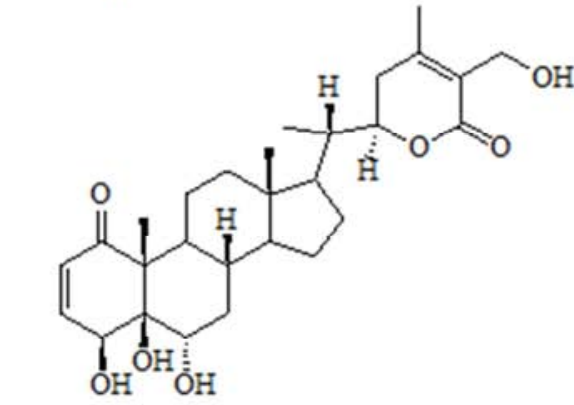

(20S,22R)-4b,5b,6a,27-tetrahydroxy-1-0xowith-2,24-dienolide<smiles>CC1=C(C)C(=O)OC([C@](C)(O)C2CCC3C2[C@H]2C[C@@H]2[C@]2(C)CC=CC(=O)[C@@]32C)C1</smiles><smiles></smiles><smiles>CC1=C(C)C(=O)OC([C@H](C)[C@]2(C)CCC3C4C5C[C@H]5[C@@]5(C)CC=CC(=O)[C@@]5(C)[C@H]4CC[C@@]32C)C1</smiles>

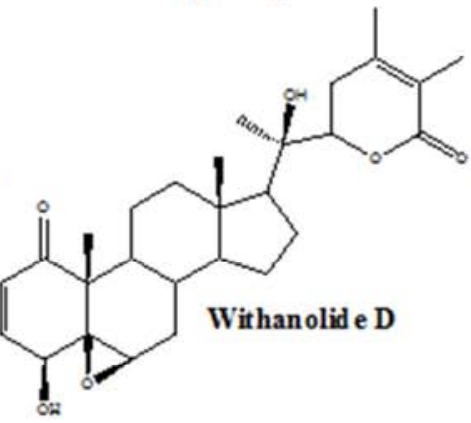

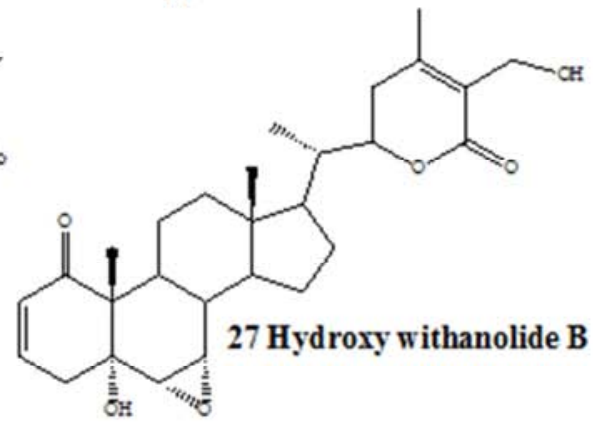

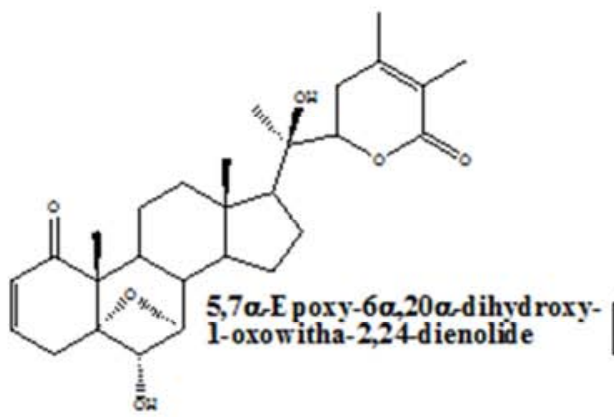

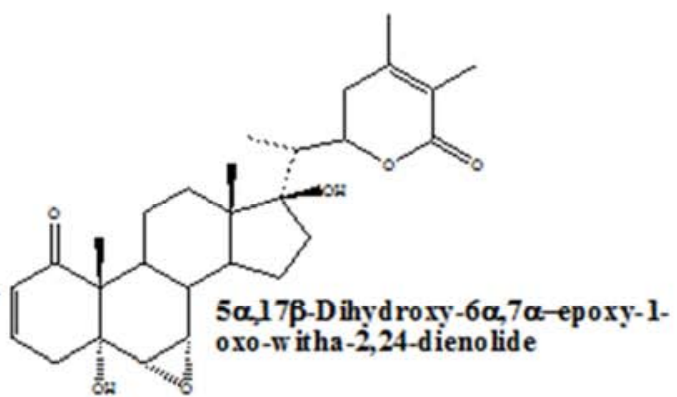

Figure 3. Possible important withanolides identified at $R_{t}$ of 8.22 minutes from the control and Biofield Energy Treated root extract of ashwagandha. 

(Ashwagandha) Root Extract Using LC-MS, GC-MS, and NMR Spectroscopy
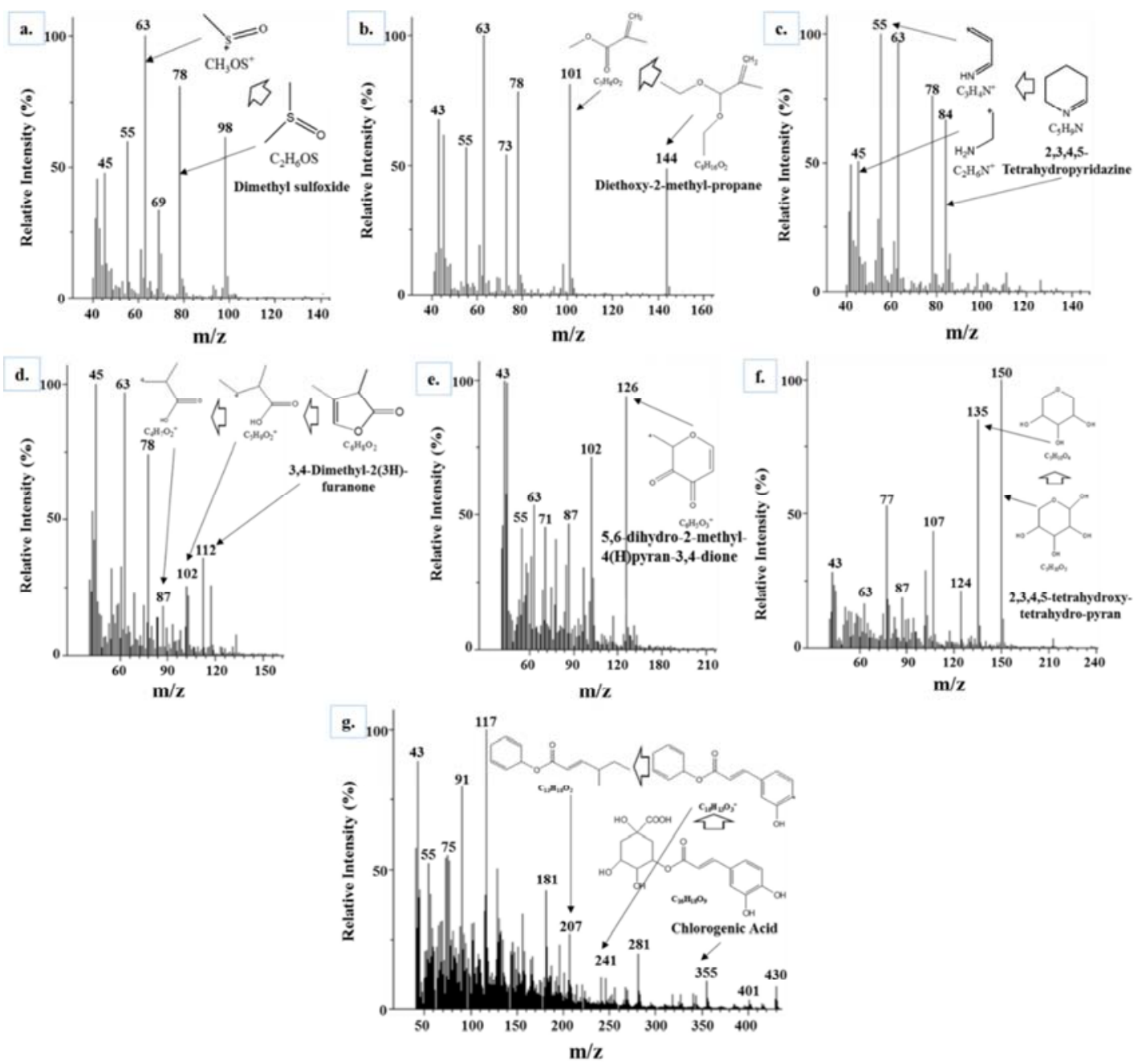

Figure 4. GC-MS spectra (a-e) of the control and Biofield Energy Treated ashwagandha root extract with the proposed fragmentation of withanolides.
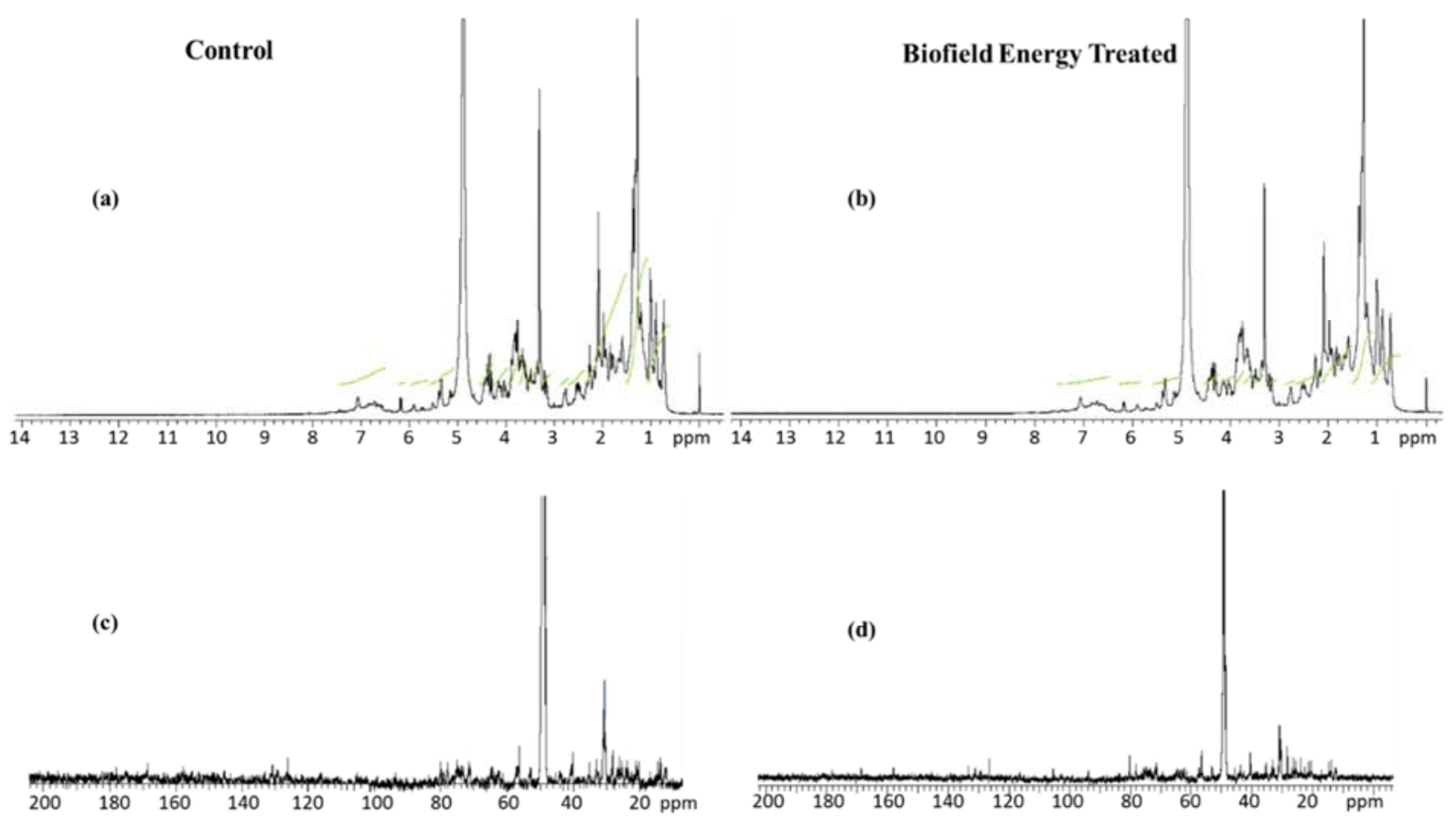

Figure 5. ${ }^{1} H$ NMR spectra of the control (a), Biofield Energy Treated (b), ${ }^{13}$ C NMR spectra of the control (c), and Biofield Energy Treated (d) Ashwagandha root extract. 


\section{Conclusions}

The current study infers that Consciousness Energy Healing Treatment (The Trivedi Effect ${ }^{\circledR}$ ) has the significant effect on the peak area $\%$ i.e. the relative concentration as well as the peak intensities of the phytoconstituents in ashwagandha root extract without affecting their structural properties. The LC-MS analysis revealed that the retention time of the phytoconstituents remained same in both the control and treated samples, whereas the peak area $\%$ at respective retention time was significantly altered. The peak area $\%$ of the treated sample at $\mathrm{R}_{\mathrm{t}}$ of 5.06, 5.24, 5.49, 5.68, $6.78,6.87,8.12,8.22,8.36,8.55,9.02$, and 10.13 minutes were significantly increased in the range of $0.27 \%$ to $146.94 \%$ compared to the control sample. In addition, the peak area $\%$ of the treated sample at $\mathrm{R}_{\mathrm{t}}$ of $5.29,5.36,6.40$, $6.49,6.56,6.67,7.08,7.37,7.76,7.87,8.02,8.43,8.85,8.97$, and 9.12 minutes were significantly decreased in the range of $1.83 \%$ to $23.53 \%$ compared with the control sample. A total of 18 withanolides such as sitoindoside IX, viscosa lactone B, 24, 25-dihydrowithanolide D, withanolide A, withaferin A, withanone, withanolide $\mathrm{D}$, ixocarpalactone A, withanolide $\mathrm{S}$, withanolide sulfoxide, etc. were proposed with their structure from the molecular mass at $m / z 650,489,473,471$, 505 , and 992 at retention times of $6.87,7.10,7.87,8.22,8.54$, and 9.11 minutes with the help of GC-MS and NMR data of both the control and Biofield Energy Treated samples. The mass peak intensity values of at the same retention time in the Biofield Energy Treated sample was significantly decreased in the range of $3.99 \%$ to $52.28 \%$ compared with the control sample. The Energy of Consciousness Healing Treatment could be valuable for altering the concentration of the phytoconstituents in the ashwagandha root extract by modifying their intrinsic physicochemical properties, which might be helpful to improve the bioavailability of active constituents present in ashwagandha root extract that might provide better therapeutic response against various diseases various diseases such as allergies, diabetes mellitus, and septic shock; stress-related disorders like sleep disorder, anxiety, insomnia, Attention Deficit Disorder (ADD), depression, Attention Deficit Hyperactive Disorder (ADHD), brain frog, low libido, impotency, mental restlessness (mind chattering), lack of motivation, fear of the future, confusion, migraines, mood swings, headaches, forgetfulness, overwhelm, worthlessness, indecisiveness, loneliness, frustration, irritability, chronic fatigue, obsessive/compulsive behavior and panic attacks; inflammatory diseases and immunological disorders like Lupus, Hashimoto Thyroiditis, Systemic Lupus Erythematosus, Type 1 Diabetes, Asthma, Tuberculosis, Hepatitis, Chronic peptic ulcers, Chronic active hepatitis, Celiac Disease (gluten-sensitive enteropathy), Crohn's disease, Graves' Disease, Addison Disease, Pernicious and Aplastic Anemia, Irritable Bowel Syndrome (IBS), Sjogren Syndrome, Multiple Sclerosis, Rheumatoid arthritis, Ulcerative colitis, Chronic periodontitis, Chronic sinusitis, Myasthenia Gravis, Diverticulitis, Atherosclerosis,
Vasculitis, Dermatitis, Rheumatoid Arthritis, Alopecia Areata, Psoriasis, Scleroderma, Reactive Arthritis, Fibromyalgia, Chronic Fatigue Syndrome and Vitiligo; aging-related diseases like cardiovascular disease, arthritis, cancer, dementia, cataracts, osteoporosis, Alzheimer's disease, diabetes, hypertension, glaucoma, Parkinson's Disease, Huntington's Disease, hearing loss, Prion Disease, Spinocerebellar Ataxia, Motor Neuron Disease, Amyotrophic lateral sclerosis, Spinal muscular atrophy, Friedreich's Ataxia and Lewy Body Disease, chronic infections and much more.

\section{Abbreviations}

DMSO: Dimethyl sulfoxide, EI: Electron impact, ESI: Electrospray ionization, LC-MS: Liquid chromatography-mass spectrometry, PDA: Photodiode Array, $\mathrm{R}_{\mathrm{t}}$ : Retention time, UPLC: Ultra-performance liquid chromatography, GC-MS: Gas chromatography-mass spectrometry, $m / z$ : Mass-to-charge ratio, NMR: Nuclear magnetic resonance spectroscopy.

\section{Acknowledgements}

The authors are grateful to GVK Biosciences Pvt. Ltd., Trivedi Science, Trivedi Global, Inc. and Trivedi Master Wellness for their assistance and support during this work.

\section{References}

[1] Kesarwani K, Gupta R (2013) Bioavailability enhancers of herbal origin: An overview. Asian Pac J Trop Biomed 3: 253-266.

[2] Singh N, Bhalla M, Jager P, Gilca M (2011) An overview on ashwagandha: A rasayana (rejuvenator) of Ayurveda. Afr J Tradit Complement Altern Med 8: 208-213.

[3] Kulkarni SK, Dhir A (2008) Withania somnifera: An Indian ginseng. Prog Neuropsychopharmacol Biol Psychiatry 32: 1093-1105.

[4] Dar NJ, Hamid A, Ahmad M (2015) Pharmacologic overview of Withania somnifera, the Indian ginseng. Cell Mol Life Sci 72: 4445-4460.

[5] Mir BA, Khazir J, Mir NA, Hasan T-ul, Koul S (2012) Botanical, chemical and pharmacological review of Withania somnifera (Indian ginseng): An Ayurvedic medicinal plant. Indian J Drugs Dis 1: 147-160.

[6] Mishra LC, Singh BB, Dagenais S (2000) Scientific basis for the therapeutic use of Withania somnifera (Ashwagandha): A review. Altern Med Rev 5: 334-346.

[7] Kumar V, Dey A, Hadimani MB, Marcović T, Emerald M (2015) Chemistry and pharmacology of Withania somnifera: An update. Tang (Humanitas Medicine) 5: e1.

[8] Bolleddula J, Fitch W, Vareed SK, Nair MG (2012) Identification of metabolites in Withania sominfera fruits by liquid chromatography and high-resolution mass spectrometry. Rapid Commun Mass Spectrom 26: 1277-1290. 
[9] Mirjalili MH, Moyano E, Bonfill M, Cusido RM, Palazón J (2009) Steroidal lactones from Withania somnifera, an ancient plant for novel medicine. Molecules 14: 2373-2393.

[10] Singh A, Duggal S, Singh H, Singh J, Katekhaye S (2010) Withanolides: Phytoconstituents with significant pharmacological activities. Int J Green Pharm 4: 229-237.

[11] Chen LX, He H, Qiu F (2011) Natural withanolides: An overview. Nat Prod Rep 28: 705-740.

[12] Budhiraja RD, Krishan P, Sudhir S (2000) Biological activity of withanolides. J Sci Ind Res 59: 904-911.

[13] Stenger VJ (1999) Bioenergetic fields. Sci Rev Alternative Med 3.

[14] Rogers, M (1989) Nursing: A Science of Unitary Human Beings. In J. P. Riehl-Sisca (ed.) Conceptual Models for Nursing Practice. $3^{\text {rd }}$ edition. Norwark: Appleton \& Lange.

[15] Rosa L, Rosa E, Sarner L, Barrett S (1998) A close look at therapeutic touch. JAMA 279: 1005-1010.

[16] Warber SL, Cornelio D, Straughn, J, Kile G (2004) Biofield energy healing from the inside. J Altern Complement Med 10: 1107-1113.

[17] Nelson LA, Schwartz GE (2005) Human biofield and intention detection: Individual differences. J Altern Complement Med 11: 93-101.

[18] Nemeth L (2008) Energy and biofield therapies in practice. Beginnings. Summer 28: 4-5.

[19] Koithan M (2009) Introducing complementary and alternative therapies. J Nurse Pract 5: 18-20.

[20] Trivedi MK, Patil S, Shettigar H, Mondal SC, Jana S (2015) The potential impact of biofield treatment on human brain tumor cells: A time-lapse video microscopy. J Integr Oncol 4: 141.

[21] Trivedi MK, Branton A, Trivedi D, Nayak G, Gangwar M, Jana S (2015) Bacterial identification using 16S rDNA gene sequencing and antibiogram analysis on biofield treated Pseudomonas fluorescens. Clin Med Biochemistry Open Access 1: 101.

[22] Trivedi MK, Branton A, Trivedi D, Nayak G, Bairwa K, Jana S (2015) Effect of biofield treatment on physical, thermal, and spectral properties of SFRE 199-1 mammalian cell culture medium. Advances in Biochemistry 3: 77-85.

[23] Trivedi MK, Branton A, Trivedi D, Nayak G, Gangwar M, Jana S (2015) Antibiogram, biochemical reactions, and genotypic pattern of biofield treated Pseudomonas aeruginosa. J Trop Dis 4: 181.

[24] Trivedi MK, Branton A, Trivedi D, Nayak G, Mondal SC, Jana S (2015) Evaluation of antibiogram, genotype and phylogenetic analysis of biofield treated Nocardia otitidis. Biol Syst Open Access 4: 143.

[25] Trivedi MK, Branton A, Trivedi D, Nayak G, Mondal SC, Jana S (2015) Antimicrobial sensitivity, biochemical characteristics and biotyping of Staphylococcus saprophyticus: An impact of biofield energy treatment. J Women's Health Care 4: 271.

[26] Trivedi MK, Branton A, Trivedi D, Nayak G, Shettigar H, Mondal SC, Jana S (2015) Effect of biofield energy treatment on Streptococcus group B: A postpartum pathogen. J Microb Biochem Technol 7: 269-273.

[27] Trivedi MK, Patil S, Shettigar H, Gangwar M, Jana S (2015) Effect of biofield treatment on antimicrobials susceptibility pattern of Acinetobacter baumannii - An experimental study. J Clin Diagn Res 3: 1.

[28] Trivedi MK, Patil S, Tallapragada RM (2013) Effect of biofield treatment on the physical and thermal characteristics of vanadium pentoxide powders. J Material Sci Eng S 11: 001 .

[29] Trivedi MK, Tallapragada RM, Branton A, Trivedi D, Nayak G, Latiyal O, Jana S (2015) Characterization of physical and structural properties of aluminum carbide powder: Impact of biofield treatment. J Aeronaut Aerospace Eng 4: 142.

[30] Trivedi MK, Tallapragada RM, Branton A, Trivedi D, Nayak G, Latiyal O, Jana S (2015) The potential impact of biofield energy treatment on the atomic and physical properties of antimony tin oxide nanopowder. American Journal of Optics and Photonics 3: 123-128.

[31] Trivedi MK, Tallapragada RM, Branton A, Trivedi D, Nayak G, Mishra RK, Jana S (2015) Biofield treatment: A potential strategy for modification of physical and thermal properties of gluten hydrolysate and ipomoea macroelements. J Nutr Food Sci 5: 414.

[32] Trivedi MK, Tallapragada RM, Branton A, Trivedi D, Nayak G, Latiyal O, Jana S (2015) Potential impact of biofield treatment on atomic and physical characteristics of magnesium. Vitam Miner 3: 129.

[33] Trivedi MK, Patil S, Shettigar H, Bairwa K, Jana S (2015) Effect of biofield treatment on spectral properties of paracetamol and piroxicam. Chem Sci J 6: 98.

[34] Trivedi MK, Branton A, Trivedi D, Shettigar H, Bairwa K, Jana S (2015) Fourier transform infrared and ultravioletvisible spectroscopic characterization of biofield treated salicylic acid and sparfloxacin. Nat Prod Chem Res 3: 186.

[35] Trivedi MK, Branton A, Trivedi D, Nayak G, Panda P, Jana S (2016) Gas chromatography-mass spectrometric analysis of isotopic abundance of ${ }^{13} \mathrm{C},{ }^{2} \mathrm{H}$, and ${ }^{18} \mathrm{O}$ in biofield energy treated $p$-tertiary butylphenol (PTBP). American Journal of Chemical Engineering 4: 78-86.

[36] Trivedi MK, Branton A, Trivedi D, Nayak G, Bairwa K, Jana S (2015) Spectroscopic characterization of disodium hydrogen orthophosphate and sodium nitrate after biofield treatment. J Chromatogr Sep Tech 6: 282.

[37] Trivedi MK, Branton A, Trivedi D, Nayak G, Sethi KK, Jana S (2016) Gas chromatography-mass spectrometry based isotopic abundance ratio analysis of biofield energy treated methyl-2-napthylether (Nerolin). American Journal of Physical Chemistry 5: 80-86.

[38] Trivedi MK, Branton A, Trivedi D, Nayak G, Gangwar M, Jana S (2016) Molecular analysis of biofield treated eggplant and watermelon crops. Adv Crop Sci Tech 4: 208.

[39] Trivedi MK, Branton A, Trivedi D, Nayak G, Mondal SC, Jana S (2015) Evaluation of biochemical marker glutathione and DNA fingerprinting of biofield energy treated Oryza sativa. American Journal of BioScience 3: 243-248. 
[40] Chatterjee S, Srivastava S, Khalid A, Singh N, Sangwan RS, Sidhu OP, Roy R, Khetrapal CL, Tuli R (2010) Comprehensive metabolic fingerprinting of Withania somnifera leaf and root extracts. Phytochemistry 71: 10851094.

[41] Chaurasiya ND, Uniyal GC, Lal P, Misra L, Sangwan NS, Tuli R, Sangwan RS (2008) Analysis of withanolides in root and leaf of Withania somnifera by HPLC with photodiode array and evaporative light scattering detection. Phytochem Anal 19: $148-154$.

[42] Musharraf SG, Ali A, Ali RA, Yousuf S, Rahman AU, Choudhary MI (2011) Analysis and development of structurefragmentation relationships in withanolides using an electrospray ionization quadropole time-of-flight tandem mass spectrometry hybrid instrument. Rapid Commun Mass Spectrom 25: 104-114.

[43] Trivedi MK, Panda P, Sethi KK, Jana S (2016) Metabolite profiling of Withania somnifera roots hydroalcoholic extract using LC-MS, GC-MS and NMR spectroscopy. Chem Biodivers (Article in press) doi: 10.1002/cbdv.201600280.

[44] https://www.scribd.com/document/220440935/Theory-ofHPLC-Quantitative-and-Qualitative-HPLC.
[45] Ghosal S, Lal J, Srivastava RS, Bhattacharya SK, Upadhyay SN, Jaiswal AK, Chattopadhyay U (1989) Immunomodulatory and CNS effects of sitoindosides IX and X, two new glycowithanolides from Withania somnifera. Phytother Res 3: 201-206.

[46] Kinghorn AD, Su BN, Lee D, Gu JQ, Pezzuto JM (2003) Cancer chemopreventive agents discovered by activity-guided fractionation: An update. Current Organic Chemistry 7: 213226.

[47] Mulabagal V, Subbaraju GV, Rao CV, Sivaramakrishna C, Dewitt DL, Holmes D, Sung B, Aggarwal BB, Tsay HS, Nair MG (2009) Withanolide sulfoxide from Aswagandha roots inhibits nuclear transcription factor- $\mathrm{\kappa B}$, cyclooxygenase and tumor cell proliferation. Phytother Res 23: 987-992.

[48] Subbaraju GV, Vanisree M, Rao CV, Sivaramakrishna C, Sridhar P, Jayaprakasam B, Nair MG (2006) Ashwagandhanolide, a bioactive dimeric thiowithanolide isolated from the roots of Withania somnifera. J Nat Prod 69: 1790-1792. 